\title{
The Effect of Ambient Scents on Consumer Responses: Consumer Type and His Accompaniment State as Moderating Variables
}

\author{
Rym Bouzaabia $^{1}$ \\ ${ }^{1}$ Institute of High Business Studies of Sousse (IHEC-Sousse), University of Sousse, Tunisia \\ Correspondence: Rym Bouzaabia, Institute of High Business Studies of Sousse (IHEC-Sousse), University of \\ Sousse, Tunisia. Tel: 216-20-255-684. E-mail: rymb060@gmail.com
}

Received: August 24, 2013

Accepted: October 2, 2013 Online Published: January 22, 2014

doi:10.5539/ijms.v6n1p155

URL: http://dx.doi.org/10.5539/ijms.v6n1p155

\begin{abstract}
The aim of this research is to study the effect of ambient scents on consumers' responses and in particular the moderating effect of consumer type (hedonic vs utilitarian) and his accompaniment state (accompanied vs single).

An experiment was conducted in a real business context (NIKE store), where 400 customers were surveyed. The results indicate that a pleasant ambient scent improves evaluation of store environment, products, quality of services provided, the level of pleasure experienced, the level of stimulation, their intention to revisit the store and customers' spending. However, ambient scents have no effect on the real time spent in the store. Finally, in the presence of an ambient scent, it was found that hedonic customers intend more to revisit the store than utilitarian ones and that accompanied customers tend to spend more and have more fun shopping than single customers.
\end{abstract}

Keywords: store atmospherics, scent, consumer behavior, hedonic consumer, utilitarian consumer, consumer accompaniment state

\section{Introduction}

The current economic landscape experiences now a turning point, in which the only survivors are the most competitive. Indeed, the reasons why the market is becoming more and more difficult to keep up with are many. Firstly, less and less differentiated products and services make it difficult for retailers to sell their stocks and to offer themselves a place in the market. Second, the development of e-commerce is not without disadvantages. Indeed, with all the benefits that e-buying offers to consumers in terms of time, price and delivery time, and despite the problems of trust towards merchant sites, fewer and fewer consumers visit outlets to make their purchases. Finally, the act of consumption has undergone deep changes over the last century and the last decade. The different socio-historical developments have transformed consumption patterns, and contrary to the trend of material consumption that existed before, we now consume to produce social identity or experience, with an appeal for the intangible (Rochefort, 1995). In our post-modern society, consumer society changed attitudes towards leisure: Consumption is cherished and considered an experience-rewarding to consumers looking for hedonism in their purchases (Caru \& Cova, 2003; Filser, 2002; Holbrook \& Hirschman, 1982). Thus, hedonism and the growing maturity of consumers who are becoming increasingly demanding and selective make the task even more difficult for retailers.

Such threats have forced distributors to adapt their offers to ensure their sustainability and their profitability.

It is in this context that the managerial applications of experiential marketing, especially olfactory marketing, were a great commercial success in many different economic sectors, in various classes of products such as cosmetics, hygiene, interior design, automotive, textile, food and catering.

Indeed, retailers realized the potential olfactory elements and other environmental factors offer, although they still use them mostly intuitively. However, scent marketing is not confined to professionals; academic research is also interested in understanding its functioning and its effects on consumer responses. Paradoxically, if the commercial use of olfaction is a great success, academic research in this area is still in its infancy, opening the path for more empirical research (Maille, 2001). 
Thus, in our research we will examine the effect of the presence vs absence of a nice ambient scent on customer responses in a ready-to-wear store. We focus in particular the moderating role of customer-type (hedonic vs. utilitarian) and the consumer accompaniment state (single vs. accompanied).

Then, our paper is structured as follows. We first expose a synthesis of studies of olfactory marketing to justify the theoretical and practical feasability of the study. Then we will present the methodology and the main results of a field survey in a real business environment: the NIKE store at the "Champs Elysées" mall in Tunisia, of 400 customers. Finally, we conclude with the theoretical and managerial contributions of this study and propose future research avenues.

\section{Review of the literature}

\subsection{The Influence of Ambient Scents on Cognitive Reactions}

A physiological study of the brain performed with individuals placed in a scented environment states that the waves recorded by the EEG reveal a cognitive activity caused by the presence of an ambient scent (Lorig \& Roberts, 1990).

Furthermore, another study showed that ambient scent could improve assessments of photographs presented to the subjects (Kirk-Smith \& Booth, 1992).

Some studies have shown that the repetition of a perfume can be a memorizing factor. Can and Ross (1989) showed that the diffusion of the same scent (versus no scent or a different scent) during learning and memorizing pictures increases recognition performance and thus memory performance, the same like memorizing words. The results of Morrin and Ratneshwar (2000) prove the same. These two authors studied the impact of spreading a pleasant ambient scent on memorizing names of known and unknown brands. Their research indicated that in the presence of a geranium scent, the recall task is particularly better for unknown brands. These results can be explained by a greater evaluation time in the presence of a pleasant scent.

Spangengberg et al. (1996) showed that the presence of a pleasant ambient scent allows for a better assessment of the store, the store environment, goods in general or specific products. Similarly, Chebat and Michon (2003) highlighted the positive effect of the presence of pleasant scents on the assessment of the global environment and the products featured in this space. Rotton (1983) was able to highlight the negative impact of an unpleasant scent on the evaluation of paintings, pictures of people or their descriptions. Finally, it seems that a nice room smell improves the quality of service encounter (Baron, 1981), but also provides a better assessment of service quality (Chebat \& Michon, 2003; Maille, 2005). Hence, we formulate our research hypotheses H1, H2 and H3.

H1: Diffusion of a pleasant ambient sent positively influences assessment of the overall store environment.

H2: Diffusion of a pleasant ambient sent positively influences assessment of the offered products.

H3: Diffusion of a pleasant ambient sent positively influences assessment of the quality of offered services.

\subsection{The Influence of Ambient Scents on Affective Reactions}

Unlike taste, there is no universally appreciated scent. Hedonic nature of scents is then fully learned.

Moch \& Bonnefoy (1997) highlight in this regard that it is generally considered that the vast majority of emotional responses to scents is acquired by learning in the family and cultural contexts we have been immersed in from childhood.

This association between scents and emotions is explained by the fact that scents are processed more directly in the limbic system than other sensory neurons (Gibbons, 1986). A scent has been described as an emotional sense as opposed to the so-called "Cognitive" senses like seeing and hearing (Engen, 1982).

Sugano (1992) and Lorig (1992), have established the effect of some scents on measures of physiological activity. For example, appearance of alpha waves in EEG indicates low arousal. Increases in CNV (Contingent Negative Variation) and blood circulation showed in turn an increase in arousal. Finally, increases in micro-vibrations reflect intellectual or muscle tensions.

Knasko (1995) showed that a pleasant scent is associated with a positive mood in the case of a museum visit. Leenders et al. (1999) showed that the presence of a lemon scent (vs. no scent) positively influences the emotional state of an individual in a supermarket.

In general, the presence of a pleasant scent seems to improve mood and increase level of enjoyment, whereas an unpleasant scent seems to deteriorate that emotional state (Ehrlichman \& Bastone, 1992). 
Furthermore, the authors find that in the case of a pleasant scent, the effects do not persist over time. Together, the judgment of pleasantness evolves towards neutrality. However, in the case of an unpleasant scent, the effects last longer.

Other studies have shown that the diffusion of a pleasant ambient scent may also increase level of customers' stimulation (Guichard et al., 1998; Leenders et al., 1999). Hence, we formulate our research hypotheses H4 and H5.

H4: Diffusion of a pleasant ambient sent positively influences level of enjoyment of customers.

H5: Diffusion of a pleasant ambient sent positively influences level of stimulation of customers.

\subsection{The Influence of Ambient Scent on Conative Reactions}

Knasko (1989) conducted an experiment during several weeks in a jewelry store. The experiment was conducted in two distinct conditions, one being unscented, and one scented with one of the following scents: a Floral / Fruity fragrance or a spicy smell. The results indicate that when scent is present, men and women spend more time in the floral / fruity condition. However, the use of a spicy scent had no effect on men.

Similarly, Gueguen and Petr (2006) showed in their experiments in a restaurant in which they diffused is a lemon scent, a scent of lavender compared to no scent (control condition), lavender scent but not lemon significantly increases the real time spent in the restaurant. The authors explained these results by the pleasant nature and the relaxing effect of lavender.

Other empirical studies conducted confirmed the existence of a significant positive relationship between the presence of pleasant scents and the real time spent in the store (Bone \& Ellen, 1999; Daucé, 2000; Hirsch, 1995; Knasko, 1995; Leenders et al., 1999).

Hirsh (1995) showed that slot machines players in Las Vegas casinos spend more money as they play in a scented environment. The same results were noticed in a clothing store (Terrling et al., 1992), a shoe shop, as well as a Piza restaurant (Gueguen \& Petr, 2006). These positive results are encouraging since they were obtained under real conditions.

Spangenberg et al. (1996) found that subjects in a scented condition express a strong desire to revisit the store. However, the authors have shown that ambient scents did not significantly increase purchase intentions for products which consumers already favor. However, Hirsh and Gay (1991) indicate that purchase intentions are improved when a floral scent is diffused and this, whatever the intensity of the scent and the preferences of individuals towards such a scent. Finally, Mattila and Wirtz (2001) pointed to the positive effect of a stimulating versus relaxing scent on intention to revisit. Hence our research hypotheses H6, H7 and H8 are as follows.

H6: The diffusion a pleasant ambient sent positively influences the intention to revisit the store.

H7: The diffusion a pleasant ambient sent positively influences customer spending.

H8: The diffusion a pleasant ambient sent positively influences the real time spent in the store.

\subsection{The Moderating Effect of Consumer Type (Hedonic Vs. Utilitarian)}

We distinguish two groups of customers, hedonic or utilitarian (Babin et al., 1994; Babin \& Attaway, 2000).

- Hedonic customers are more oriented towards the environment's sensory dimensions. They are sensitive to external environment elements and take pleasure in shopping (Cottet \& Vibert, 1999). For this group of consumers, shopping is recreational and social (Downs, 1961).

- In contrast to hedonic customers, utilitarian experience less pleasure and stimulation to shop. They are less attracted to shopping malls. These visitors are much less likely to consider environmental factors. They do not bond with vendors and are more influenced by price than any other factor. They make little or unplanned impulse purchases, spend a lot less time shopping than hedonic customers and consider shopping as a necessity rather than pleasure (Cottet \& Vibert, 1999).

To our knowledge, no study to date has addressed the moderating role of customer type (utilitarian or hedonic) in ambient scents effects.

However, we can assume that the effects of ambient scents on emotional states, perceptions and behavior will be moderated by consumer type (Hedonic / utilitarian). Hedonic customers are more sensory dimension-oriented seeking sensation or hedonic gratification than utilitarian customers. Thus, the presence of a pleasant ambient scent could have a greater and more positive impact on hedonic customers' cognitive, affective and conative responses than utilitarian customers. 
However, utilitarian customers are directed to the environment's cognitive dimension (thoughts) and visit malls for functional reasons (collect or obtain information about a service or a product without much delay). They will be less influenced by environment's sensorial elements like its scent, thus:

H9: Consumer type (hedonic vs. utilitarian) moderates the effect of ambient scents on cognitive responses:

- H9.1.: Assessment of the overall store environment

- H9.2.: Assessment of the offered products

- H9.3.: Assessment of the quality of offered services

H10: Consumer type (hedonic vs. utilitarian) moderates the effect of ambient scents on affective responses:

- H10.1.: Pleasure

- H10.2.: Stimulation

H11: Consumer type (hedonic vs. utilitarian) moderates the effect of ambient scents on conative responses:

- H11.1.: The real time spent in the store

- H11.2.: The amounts spent

- H11.3.: The intention to revisit the store

\subsection{The Moderating Effect of Consumer Accompaniment State}

To our knowledge no study to date has dealt with the moderating role of consumer accompaniment state (accompanied vs single) in the relationship between ambient scents and customers responses in a retail context. However, consumer accompaniment state represents an important dimension of the consumption experience.

The few studies in marketing interested in this variable examined the role, history and impact on individual behavior of visitor accompaniment state, of entertainment venues and more specifically museums.

DeBenetti (2001) claims that accompanied visitors tend to consume more than single ones. These latter often stop at the bar or restaurant. Time-wise, the author points out those single customers spend less time in a museum. Hood (1994) explains this difference in behavior in that the museum's annexed services represent factors for social interactions between visitors. Moreover, the author further explains that single visitors are more focused on the core of the consumption experience rather than on the experiential dimension of the offer (McManus, 1994).

In other words, single customers are proved to be the most focused on the functional dimension of the offer (like the main offered product). Subsequently, accompanied visitors are more oriented and sensitive to the experiential dimension of the offer, encouraging social interaction among customers.

Therefore, it would be interesting to study this variable in a retail context and put customers in an intimate social context during their visit to a shopping center, in particular a point of sale, bearing in mind the distinction between accompanied and single customers.

H12: The consumer accompaniment state (accompanied vs. Single) moderates the effect of ambient scents on cognitive responses:

- H12.1.: Assessment of the overall store environment

- H12.2.: Assessment of the offered products

- H12.3.: Assessment of the quality of offered services

H13: The consumer accompaniment state moderates the effect of ambient scents on affective responses:

- H13.1.: Pleasure

- H13.2.: Stimulation

H14: The consumer accompaniment moderates the effect of ambient scents on conative responses:

- H14.1.: The real time spent in the store

- H14.2.: The amounts spent

- H14.3.: The intention to revisit the store 


\section{Method}

\subsection{Sample and Data Collection}

In order to test our research hypothesis, an experiment, involving a sample of 400 individuals, $50 \%$ of which are accompanied and 50\% are single, was conducted in a ready-to-wear "NIKE" store in the "Les Champs Elysées" shopping center Tunisia (Table 1). To this effect, we administered a face to face questionnaire.

Table 1. Experimental plan

\begin{tabular}{ll}
\hline Scented condition & Sample \\
\hline Control condition: & 200 \\
$\begin{array}{l}\text { Absence of a pleasant ambient scent } \\
\text { Experimental condition: }\end{array}$ & 200 \\
Presence of a pleasant ambient scent (Ylang Ylang scent) & \\
Total & 400 \\
\hline
\end{tabular}

The "NIKE" brand was selected because it has a strong marketing department interested in the concept of sensorial marketing, in particular olfactory marketing, hence their full cooperation. Moreover, none of the items sold in the "NIKE" store issues any detectable scent and therefore can not be interpreted as particularly scented.

To achieve our aims, we manipulated the condition of ambient scents in the above-mentioned store, all things being equal for the other atmospheric variables. We insisted that the store manager diffuses the same background music and keep the same environment set during our experimentation. Similarly, we have controlled the ambient scent's diffusion intensity.

The scent diffuser has been installed in an unseen corner of the store around the fitting rooms and connected to the central air conditioning system. Three-second scent sprays every six minutes were set allowing for a perfect rendition of the scent and a rapid, dry, homogeneous and subtle diffusion providing excellent olfactory comfort.

The choice of the scent for the purpose of our experiment was inspired by the study of Spangenberg et al. (1996). Consistent with many studies (Daucé, 2000; Roullet, 2004), the choice of the olfactory stimuli in our experiment is made by carrying out a pre-test on a small sample of the target population, ie customers of the store where the final experiment will take place. Therefore, for the purposes of this study, we pre-tested 5 floral scents; wood, citrus, spices and mint to check the hedonic nature of each.

All scents were essential natural oils from a single supplier. As for the subjects of the pretest, a convenience sample of 50 customers, intercepted near the store entrance. After making sure that the different subjects showed no scents-related allergies, we invited them to smell for two minutes cotton balls soaked in each olfactory stimuli of the experiment held in opaque flasks. Finally, subjects were asked to evaluate the stimulating nature, approval and familiarity of each odor. For this purpose, we used four items of the scale of Daucé (2000) measured on a semantic differential continuum (attractive / unattractive, pleasant / unpleasant, stimulating / relaxing, motivating /less motivating), itself inspired by the scale of Fisher (1974), and perceived familiarity measurement scale (familiar / Not familiar) to assess the presented scents (Crowley, 1993; Spangenberg et al., 1996).

To select the scent that will serve as a stimulus in our experiment, we classified scents according to the means of approval, stimulation and familiarity (Table 2).

Table 2. Results of the pre-test for "scents"

\begin{tabular}{llllll}
\hline Scent category & Individual scent tested & $\begin{array}{l}\text { Number of } \\
\text { participants }\end{array}$ & Approval & Stimulation & Familiarity \\
\hline flowers & Ylang Ylang & 50 & 0.585 & 0.680 & 1.780 \\
Spices & Cinnamon & 50 & 0.003 & -0.734 & 4.260 \\
Woods & Sandalwood & 50 & -0.565 & -0.386 & 3.560 \\
Citrus & Citrus: (orange; lemon and & 50 & 0.320 & 0.624 & 2.720 \\
& grapefruit) & & & & \\
Mint & Green mint & 50 & -0.343 & -0.183 & 4.060 \\
\hline
\end{tabular}


The above results indicate that the Ylang Ylang and citrus scents have the best means of approval, but also considered as the most stimulating. The retained scent that has the advantage of being neutral in terms of congruence or incongruence with the products sold in the store and with the cleaners used in the store and did not prime special memories, as recommended by Spangenber et al. (1996), is the Ylang Ylang scent.

The scent used for the purposes of our experiment was provided to us by the only consulting olfactory communication agency in Tunisia "Ylang" created in June 2003 and whose partners are:

- The European leader in olfactory Marketing "Prolitec" which has developed a technology that transforms under low-temperature a pure scent concentrate into scent particles below one micron in size which behave like a gas, completely dry, with constant output to avoid olfactory pollution, deposit and impregnation.

- The house creating perfumes and scents, originally-manufactured and customized "Créassence".

\subsection{Measurement Scales}

In the first step, we conducted an exploratory factor Analysis with a varimax rotation to purify and assess the dimensionality of constructs (Appendix 1).

In the second step, we conducted a confirmatory factor analysis on AMOS 18.0 to test the reliability and validity of each measurement scale (Appendix 2).

The emotional responses scale was measured with items adapted from Daucé (2000). This scale consisted of seven_items measured by 7-point semantic differential scales.

The assessment of the overall environment of the store was measured with seven items under a 7-point semantically differentiated scale, adapted from Daucé (2000).

Assessment the products offered by the "NIKE" store was measured by four semantically differentiated scales with 7 points adapted from Bellizzi et al. (1983).

To measure assessment of the quality of services offered by the "NIKE" store, we used a 7-point semantically differentiated scale adapted from Taylor (1996).

To measure the intention to revisit the store, we used the scale proposed by Spangenberg et al. (1996). This is a one-item, and a 7-point semantically differentiated scale. For the real time spent in the store, time records were made in the store throughout the test period. These surveys may be related or unrelated to questionnaire administration. To measure the expenditure of store customers, we asked them: How much money did they spend? Finally, to measure consumer type, we use Babin et al. (1994) measure which has been validated in a real retail environment by Chebat et al. (2005). This scale consists of seven items and measured by a 5 point Likert scale ranging from "Strongly agree" to "Strongly disagree."

\section{Results}

Our study examines the effect of the presence vs. absence of a nice ambient scent on customers' cognitive, affective and conative responses. Thus, it is necessary to test the effect of our independent variable "ambient scent" by conducting one-factor analysis of variance. The results are presented in Table 3 as follows:

Table 3. Results of the one-factor analysis of variance

\begin{tabular}{llllll}
\hline Dependent variables & $\mathrm{F}$ & Sig. & & Absence & Presence \\
\hline $\begin{array}{l}\text { Assessment of the overall } \\
\text { store environment }\end{array}$ & 406,957 &, 000 & +++ &,- 713 &, 678 \\
$\begin{array}{l}\text { Assessment of the offered } \\
\text { products }\end{array}$ & 533,926 &, 000 & +++ &,- 755 &, 761 \\
$\begin{array}{l}\text { Assessment of the quality of } \\
\text { the offered services }\end{array}$ & 324,073 &, 000 & +++ & 3,353 & 5,707 \\
$\begin{array}{l}\text { Pleasure } \\
\text { Stimulation }\end{array}$ & 139,940 &, 000 & +++ &,- 527 &, 473 \\
Intention to revisit the store & 229,576 &, 000 & +++ &,- 611 &, 588 \\
Amounts spent & 236,278 &, 000 & +++ & 3,060 & 5,383 \\
Real time spent & 6,612 &, 010 & ++ & 2,139 & 2,592 \\
\hline
\end{tabular}


The results below indicate clearly that assessment of the overall store environment, assessment of the offered products, assessment of the quality of services, level of experienced pleasure, level of stimulation, intention to revisit the store and the amounts spent vary significantly depending on the presence (vs. absence) of a pleasant ambient scent (Table 4). In fact, customers have better assessments, felt greater pleasure and stimulation, expressed intention to revisit the store and spent more in a scented environment than in an unscented one (Table 3). Thus, we confirm our hypotheses (H1, H2, H3, H4, H5, H6, H7) and we reject hypothesis (H8). In fact, it seems that the diffusion of an ambient scent in the store has no effect on real time spent by customers.

- Moderating effects of consumer type (Hedonic vs Utilitarian) and consumer accompaniment state (Accompanied vs. Single)

The moderating role of our variables (consumer type and consumer accompaniment state) will be tested by an analysis of variance in which the moderator variable will be inserted as a fixed factor. Moderation is accepted provided that there is a significant interaction effect of the moderator variable and the independent variable on the dependent variable (Sharma et al., 1981).

Our continuous variable "consumer type" processed as two classes; Hedonic vs Utilitarian, using a "Two-Step Cluster Analysis", a method adopted by Drugeon-Lichtlé (1998) and Helm-Guizon (1997).

The table 4 summarizes the results of the interaction between consumer type consumer (hedonic versus utilitarian), consumer accompaniment state (accompanied vs single) and ambient conditions (presence vs. absence of ambient scent) and customers reactions. We are now able to confirm or refute our research hypotheses on the moderating effects of the two variables: consumer type and consumer accompaniment state.

Table 4. Summary of results for the moderating variables "consumer type (hedonic versus utilitarian)" and "consumer accompaniment state (accompanied vs single)"

\begin{tabular}{|c|c|c|c|c|}
\hline \multirow[t]{2}{*}{ Dependent variables } & \multicolumn{2}{|c|}{ Consumer type $\mathrm{x}$ Ambient condition } & \multicolumn{2}{|c|}{$\begin{array}{l}\text { Consumer accompaniment state } \mathrm{x} \\
\text { Ambient condition }\end{array}$} \\
\hline & $\mathrm{F}$ & Sig & $\mathrm{F}$ & Sig \\
\hline $\begin{array}{l}\text { Assessment of the overall store } \\
\text { environment }\end{array}$ & 2,735 & 099 & 0,201 & 654 \\
\hline $\begin{array}{l}\text { Assessment of the offered } \\
\text { products }\end{array}$ &, 064 &, 801 &, 045 &, 831 \\
\hline $\begin{array}{l}\text { Assessment of the quality of } \\
\text { the offered services }\end{array}$ & 1,306 &, 254 & 0,306 & ,234 \\
\hline Pleasure &, 537 & ,464 & 9,645 &, 002 \\
\hline Stimulation &, 180 & ,672 & 2,195 & ,139 \\
\hline Intention to revisit the store & 8,866 &, 003 & 0,240 & ,625 \\
\hline Amounts spent & 002 & ,968 & 11,374 & ,001 \\
\hline Real time spent & \multicolumn{2}{|c|}{$\begin{array}{l}\text { No effect (principal) of ambient scent on } \\
\text { real time spent was dtected. }\end{array}$} & \multicolumn{2}{|c|}{$\begin{array}{l}\text { No effect (principal) of ambient scent } \\
\text { on real time spent was dtected. }\end{array}$} \\
\hline
\end{tabular}

From the above results, we notice there is no significant interaction between consumer type and ambient condition on the cognitive, affective and conative responses. Therefore, hypotheses H9, H10, H11.1 and H11.2 are rejected. However, consumer type acts as a moderating variable at the level of the effect of ambient scent on the intention to revisit the store. To know the meaning of moderation, means of the variable "intention to revisit the store" were calculated by distinguishing two customer groups as hedonic or utilitarian. Therefore, we can assume that hedonic customers intended more to revisit the "NIKE" store than utilitarian customers and this is true whatever the ambient condition in which they are located (C1 and $\mathrm{C} 2$ ), with a peak at $\mathrm{C} 1$ (Table 5). 
Table 5. Means of intention to revisit the "NIKE" store according the "consumer type"

\begin{tabular}{llll}
\hline Dependent variable & Ambient condition & Consumer type & Mean \\
\hline Intention to revisit the store & $\begin{array}{l}\text { Presence of Ylang Ylang scent } \\
(\mathrm{C} 1)\end{array}$ & Utilitarian & 10,382 \\
& Hedonic & 44,065 \\
& $\begin{array}{l}\text { Absence of Ylang Ylang scent } \\
\text { (C2) }\end{array}$ & Utilitarian & 11,899 \\
& Hedonic & 37,554 \\
\hline
\end{tabular}

As for consumer accompaniment state, it is found to moderate the relationship between ambient scents, felt pleasure and amounts spent. Therefore, we confirm hypotheses H13.1 and H14.2 (Table 6). Average level of felt pleasure, and amounts spent by accompanied consumers are greater than those of single ones, and this whatever the ambient condition in which they are located ( $\mathrm{C} 1$ and $\mathrm{C} 2$ ), with a peak at $\mathrm{C} 1$ (Table 6 and Table 7).

Table 6. Mean of pleasure according the "consumer accompaniment state"

\begin{tabular}{llll}
\hline Dependent variable & Ambient condition & Consumer accompaniment state & Mean \\
\hline Pleasure & Presence of Ylang Ylang scent (C1) & Single & 0,121 \\
& Accompanied & 3,456 \\
& & 0,108 \\
& Absence of Ylang Ylang scent (C2) & Single & 1,189 \\
& Accompanied & \\
\hline
\end{tabular}

Table 7. Mean of amounts spent according the "consumer accompaniment state"

\begin{tabular}{llll}
\hline Dependent variable & Ambient condition & Consumer accompaniment state & Mean \\
\hline Amounts spent & $\begin{array}{l}\text { Presence of Ylang Ylang scent } \\
(\mathrm{C} 1)\end{array}$ & Single & 1,152 \\
& Accompanied & 6,367 \\
& $\begin{array}{l}\text { Absence of Ylang Ylang scent } \\
\text { (C2) Single }\end{array}$ & 1,065 \\
& Accompanied & 3,186 \\
\hline
\end{tabular}

\section{Discussion}

Our study has checked through an experiment conducted in partnership with a ready-to-wear "NIKE" store, the effect of ambient scents on customers' cognitive (assessment of the overall environment of the store, offered products and the quality of offered services), affective (pleasure and stimulation) and conative (intention to revisit the store, real time spent and money spent) responses. We have in particular checked the moderating effect of consumer type (Hedonic vs Utilitarian) and his accompaniment state (Accompanied vs. Single).

\subsection{Limitations}

First, the act of conducting our study in a real store makes it difficult to control exogenous variables. Indeed, consumer behavior can be influenced by uncontrolled factors. For example, other atmospheric variables, including ambient music, interior design or crowdedness of the store may interact with ambient scents and trigger different effects on customers (Kotler, 1974; Mattila \& Wirtz, 2001).

Then, the external validity of our study and therefore its generalizability is limited because of validity requirements. The selection of a particular cultural context "Tunisia" and "NIKE" store is a case in point. Indeed, if local or contact personnel differ from one outlet to another, customers do also; from one neighborhood to 
another, from one region to another, but also from one country to another. Therefore it is important to explore more experimental sites, and more store types.

Finally, despite the limitations just mentioned, our study is interesting in more than one way. Its contribution lies in both the theoretical and operational levels.

\subsection{The Theoretical and Managerial Contributions}

The first contribution of our research was to highlight the importance of developing retail spaces. Indeed, brands should develop spaces where they can build a special relationship with their customers.

Our research has highlighted the interest of disseminating ambient scents to positively influence customers' cognitive, affective and conative responses, but also to highlight the need to take into account consumer type (hedonic vs. utilitarian) and their accompaniment state (accompanied vs single) as moderating variables between ambient scents and customer responses.

Managerial contributions of this study relate essentially to store atmospherics and in particular olfactory elements which should be considered by practitioners as a management tool likely to affect their customers' cognitive, affective and conative reactions.

In our study, we noticed that consumer type and consumer accompaniment state could moderate the sensitivity of the latter to the presence vs absence of a pleasant ambient scent. Hedonic customers intend more to revisit the store in the presence of a pleasant ambient scent. Similarly, accompanied customers spend more and express more pleasure than single customers in the presence of a pleasant ambient scent.

Consequently, managers should consider the importance of the variables: consumer type and his accompaniment state. They should attach a Particular interest to the experiential dimension of their offer and in Particular olfactory elements in view of attracting hedonic consumers looking for a pleasant shopping experience. Also, they should attend to eliminate elements that may be perceived as barriers to social interaction between companions such as unpleasant atmosphere (unpleasant odor, very loud music...) to lead them to spend more and have more fun shopping.

Finally, we point out that the NIKE store decided to pursue the experiment in several of its stores in Tunisia.

\subsection{Future Research}

From the literature and the obtained preliminary results, we can point to several avenues of future research. First, future research should examine other characteristics of scents (such as scent intensity and its stimulating nature) other than the approval characteristic. Moreover, future research should consider other environmental factors (such as music, color, lighting, crowd...) that may interact with the effect of ambient scents on customer responses.

It would also be interesting to introduce in the general model that we proposed other moderating variables such as gender, age, optimum stimulation level (OSL), identity of companions etc. (Bitner, 1992; Debenedetti, 2003; Maille, 2005).

Furthermore, in order to increase external validity of our research, it would be desirable to repeat this research in a variety of stores to consider generalizing some the obtained results.

Dissemination of scents still poses today implementation difficulties. The ideal diffuser remains still to be developed and choosing the scent still is not simple. This can be done by setting up conditions and specifications by which different customers can provide tailored scents.

\section{References}

Babin, B. J., \& Attaway, J. S. (2000). Atmospheric Affect as a Tool for Creating Value and Gaining Share of Customer. Journal of Business Research, 49, 91-99. http://dx.doi.org/10.1016/S0148-2963(99)00011-9

Babin, B. J., Darden, W. R., \& Griffin, M. (1994). Work and/or fun: measuring hedonic and utilitarian Shopping Value. Journal of Consumer Research, 20, 644-646. http://dx.doi.org/10.1086/209376

Baron, R. A. (1981). Olfaction and human Social behavior: Effects of a pleasant Scent on attraction and Social perception. Personality and Social Psychology Bulletin, 7(4), 611-616. http://dx.doi.org/10.1177/014616728174016

Bellizi, J. A., Crowley, A. E., \& Hasty, R. W. (1983). The effects of color in store design. Journal of Retailing, $59(1), 23-45$. 
Ben Dahmane Mouelhi, N. (2007). The joint influence of ambient factors on customer behavior: The case of music and ambient odor. Ph.D. Dissertation. University de Caen/Basse-Normandie.

Bitner, M. J. (1992). Servicescapes: the impact of physical surrounding on customers and employees. Journal of Marketing, 56(2), 57-71. http://dx.doi.org/10.2307/1252042

Bone, P. F., \& Ellen, P. S. (1999). Scent in the market place: explaining a fraction of olfaction. Journal of Retailing, 75(2), 243-262. http://dx.doi.org/10.1016/S0022-4359(99)00007-X

Cann, A., \& Ross, D. A. (1989). Olfactory stimuli as context cues in human memory. American Journal of Psychology, 102(1), 91-102. http://dx.doi.org/10.2307/1423118

Caru, A., \& Cova, B. (2003). Approche empirique de l'immersion dans l'expérience de consommation: Les opérations d'appropriation. Recherche et Applications en Marketing, 17(2), 41-53.

Chebat, J. C., \& Michon, R. (2003). Impact of Odors on Shoppers Emotions, Cognition and Spending: A test of Competitive Causal Theories. Journal of Business Research, 56, 529-539. http://dx.doi.org/10.1016/S0148-2963(01)00247-8

Chebat, J. C., Eroglu, S. A., \& Machleit, K. A. (2005). The interaction of retail density and music tempo: Effects on shopper responses. Psychology and Marketing, 22(7), 577-589. http://dx.doi.org/10.1002/mar.20074

Cottet, P., \& Vibert, F. (1999). La Valorisation Hédonique et/ou utilitaire du Shopping dans le Magasin d'usines. 15ème Congré International de l'Association Française du Marketing. Strasbourg. Mercredi 19 et Jeudi 20 Mai. Tome 1: 93-116.

Crowley, A. E. (1993). The two-dimensional impact of color on shopping. Marketing Letters, 4(1), 59-69. http://dx.doi.org/10.1007/BF00994188

Daucé, B. (2000). La diffusion de senteurs d'ambiance au sein d'un lieu commercial: Les premiers résultats d'une étude menée au sein d'un magasin de prêt à porter. $16^{\text {ème }}$ Congrès International de l'Association Française du Marketing,Montréal. 18-20 mai, Tome 2: 747-756.

Debenedetti, S. (2001). Experience visiting places of entertainment: the central role of companions. Recherche et Applications en Marketing, 18(4), 43-58. http://dx.doi.org/10.1177/076737010301800403

Downs, A. (1961). A theory of efficiency. Journal of Retailing, 37, 6-12.

Drugeon-Lichtlé, M. C. (1998). The impact of the color of an advertisement on the front felt emotions announcement, attitudes and beliefs about the brand. Ph.D. Dissertation. University of Paris-Dauphine.

Ehrlichman, H., \& Bastone, L. (1992). The use of odour in the study of emotion. In S. van Toller \& G. H. Dodd (Eds.), Fragrance: The psychology and biology of perfume (pp. 143-159). Elsevier Applied Science.

Engen, T. (1982). The perception of odors. New York, NY: Academic Press.

Fisher, J. (1974). Situation specific variables as determinants of perceived environmental esthetic quality and perceived crowdedness. Journal of research in personality, 8 , 177-188. http://dx.doi.org/10.1016/0092-6566(74)90019-1

Guéguen, N., \& Petr, C. (2006). Odors and consumer behavior in a restaurant. International Journal of Hospitality Management, 25, 335-339. http://dx.doi.org/10.1016/j.jhm.2005.04.007

Guichard, N., Lehu, J. M., \& Vanheems, R. (1998). Marketing du cinquième sens :L'aromachologie au service de la stratégie marketing. Décisions Marketing, 14, 7-17.

Helm-Guizon, A. (1997). Mental imagery and effects of persuasive communication: application to a work of art included in an advertisement. Ph.D. Dissertation. University of Paris-Dauphine.

Hirsch, A. R. (1995). Effects of ambient odors on slot-machine usage in Las Vegas casino. Psychology and Marketing, 12(7), 585-594. http://dx.doi.org/10.1002/mar.4220120703

Hirsch, A. R., Gay, S. E. (1991). Effect of ambient olfactory stimuli on the evaluation of a common consumer product. Chemical Senses, 16, 115-136.

Holbrook, M. B., \& Hirschman, E. C. (1982). The experiential aspects of consumption: Consumer Fantasies, Feelings and Fun. Journal of Consumer Research, 9(2), 132-140. http://dx.doi.org/10.1086/208906

Hood. (1994). L' interaction sociale au musée, facteur d'attraction des visiteurs occasionnels. Publics et Musées, 5, 45-57. http://dx.doi.org/10.3406/pumus.1994.1036 
Kirk-Smith, M. D., \& Booth, D. A. (1992). Effects of Natural and Synthetic Odorants on Mood and Perception of other People. Chemical Senses, 17(6), 835-849.

Knasko, S. C. (1989). Ambient odor and Shopping behavior. Chemical Senses, 14(5), 719.

Knasko, S. C. (1995). Pleasant odors and Congruency: Effects on Approach Behavior. Chemical Senses, 18(5), 479-487. http://dx.doi.org/10.1093/chemse/20.5.479

Kotler, P. (1974). Atmospherics as a Marketing Tool. Journal of Retailing, 49(4), 48-64.

Leenders, M., Smidts, A., \& Langeveld, M. (1999). Effects of Ambient Scent in Supermarkets: A Field Experiment. $28^{\text {th }}$ International Conference EMAC. Berlin.

Lorig, T. S., \& Roberts, M. (1990). Odor and cognitive alteration of the contingent negative variation. Chemical Senses, 15(5), 537-545. http://dx.doi.org/10.1093/chemse/15.5.537

Maille, V. (2001). L'influence des stimuli olfactifs sur le comportement du consommateur: un état des recherches. Recherche et Applications en Marketing, 16(2), 51-74. http://dx.doi.org/10.1177/076737010101600204

Maille, V. (2005). Perfume outlets of a public service: is it sufficient that it smells good? Days Trend Marketing, January, Paris.

Mattila, A. S., \& Wirtz, J. (2001). Congruency of Scent and Music as a Driver of In-Store Evaluations and Behavior. Journal of Retailing, 77(2), 273-289. http://dx.doi.org/10.1016/S0022-4359(01)00042-2

McManus, P. M. (1994). Le contexte social, un des déterminants du comportement d'apprentissage dans les musées. Publics et Musées, 5, 59-78. http://dx.doi.org/10.3406/pumus.1994.1037

Moch, A., \& Bonnefoy, B. (1997). Odeurs et environnement urbain: Le métro parisien. Psychologie Française, 42(2), 175-182.

Morrin, M., \& Ratneshwar, S. (2000). The impact of ambient Scent on evaluation, attention, and memory for familiar and unfamiliar brands. Journal of Business Research, 49(2), 157-165. http://dx.doi.org/10.1016/S0148-2963(99)00006-5

Rochefort, R. (1995). Society of consumer. Paris.

Rotton, J. (1983). Affective and cognitive consequences of malodorous pollution. Basic and Applied Social Psychology, 4(2), 171-191. http://dx.doi.org/10.1207/s15324834basp0402_5

Roullet, B. (2004). The influence of color in marketing: Towards a neuropsychology of consumer. Thèse de Doctorat, Université de Rennes I, Décembre, 628 pages.

Sharma. S., Durand, R. M., \& Gur Arie, O. (1981). Identification and analysis of moderator variables. Journal of Marketing Research, 18, 291-300. http://dx.doi.org/10.2307/3150970

Spangenberg, E. C., Crowley, A. E., \& Handerson, P. W. (1996). Improving the Store Environment: Do olfactory cues affect evaluations and behaviors? Journal of Marketing, 60(2), 67-80. http://dx.doi.org/10.2307/1251931

Sugano, H. (1992). Psychological Studies of fragrances. In S. V. Toller \& G. Dodd (Eds.), Fragrance: The psychology and biology of perfume. Elsevier Science Publishers LTD.

Taylor, S. (1996). The role of effective states and locus of attribution in evaluations of service. Journal of Consumer Research, 13(3), 216-225.

Terrling, A., Niscdor, R., \& Koster, E. P. (1992). The effect of Ambient odors on Shopping. Chemical Senses, $17(6), 886$. 
Appendix 1. Exploratory factor analysis results

\begin{tabular}{|c|c|c|}
\hline \multicolumn{3}{|l|}{ Measurement scale 1: The emotionals responses } \\
\hline \multirow{2}{*}{$\begin{array}{l}\mathrm{KMO}=0.893 \\
\text { Rounded Khi square }=2154.283 ; \mathrm{Ddl}=15\end{array}$} & \multicolumn{2}{|l|}{ Contribution to postmen training } \\
\hline & \multicolumn{2}{|l|}{ F1 } \\
\hline Significance of Bartlett $=0.000$ & \multicolumn{2}{|l|}{$\%$ Explained Variance $=75.976 \%$} \\
\hline \multicolumn{3}{|l|}{ Cronbach Alpha $=0.928$} \\
\hline Sad / Joyful & \multicolumn{2}{|l|}{.892} \\
\hline Unhappy/Happy & \multicolumn{2}{|l|}{.899} \\
\hline Pessimistic / Optimistic & \multicolumn{2}{|l|}{.860} \\
\hline Restless/Relaxed & \multicolumn{2}{|l|}{.888} \\
\hline Upset/ Calm & \multicolumn{2}{|l|}{.854} \\
\hline Impatient/ Clear mind & \multicolumn{2}{|l|}{.835} \\
\hline \multicolumn{3}{|c|}{ Measurement scale 2: Assessment of the overall store environment } \\
\hline $\mathrm{KMO}=0.932$ & \multicolumn{2}{|l|}{ Contribution to postmen training } \\
\hline Rounded Khi square $=\mathbf{2 3 1 2 . 9 7 8}$; Ddl $=15$ & \multicolumn{2}{|l|}{ F1 } \\
\hline Significance of Bartlett $=0.000$ & \multicolumn{2}{|l|}{$\%$ Explained Variance $=80.534 \%$} \\
\hline \multicolumn{3}{|l|}{ Cronbach Alpha $=0.935$} \\
\hline Unattractive / Attractive & \multicolumn{2}{|l|}{.893} \\
\hline Depressing / Joyful & \multicolumn{2}{|l|}{.879} \\
\hline Boring / Stimulating & \multicolumn{2}{|l|}{.882} \\
\hline Bad / Good & \multicolumn{2}{|l|}{.912} \\
\hline Less motivating / Motivating & \multicolumn{2}{|l|}{.906} \\
\hline Unpleasant / Pleasant & \multicolumn{2}{|l|}{.912} \\
\hline \multicolumn{3}{|c|}{ Measurement scale 3: Assessment of the offered products } \\
\hline $\mathrm{KMO}=0.712$ & \multicolumn{2}{|l|}{ Contribution to postmen training } \\
\hline Rounded Khi square $=456.754 ; \mathrm{Ddl}=15$ & \multicolumn{2}{|l|}{ F1 } \\
\hline Significance of Bartlett $=0.000$ & $\%$ Explained Variance $=56.993 \%$ & \\
\hline Cronbach Alpha $=0.821$ & & \\
\hline Style (modern / outdated) & .860 & \\
\hline choice (suitable / unsuitable) & .836 & \\
\hline quality (good / bad) & .852 & \\
\hline price (low / high) & .639 & \\
\hline Measurement scale 4: Consumer type & & \\
\hline $\mathrm{KMO}=0.775 ;$ Rounded Khi-square $=1941.486$ & Contribution to postmen training & \\
\hline $\mathrm{Ddl}=15$ & F1: Hédoniste & F2 : Utilitariste \\
\hline Significance of Bartlett $=0.000$. & $\%$ Explained Variance $=61.836 \%$ & $\%$ Explained Variance $=$ \\
\hline & Cronbach Alpha $=0.933$ & $23.580 \%$ \\
\hline & & Cronbach Alpha $=0.851$ \\
\hline $\begin{array}{l}\text { This shopping experience was really felt like an } \\
\text { escape. }\end{array}$ & .916 & -.240 \\
\hline $\begin{array}{l}\text { In comparison to other activities that I have done, the } \\
\text { time spent shopping was really nice. }\end{array}$ & .920 & -.217 \\
\hline When shopping, I felt the sensation of adventure. & .906 & -.126 \\
\hline I loved being surrounded by new products. & .848 & -.070 \\
\hline I could not buy what I really needed. & -.107 & .936 \\
\hline $\begin{array}{l}\text { I made the purchases I wanted during my shopping } \\
\text { experience. }\end{array}$ & -.216 & .916 \\
\hline
\end{tabular}


Appendix 2. Confirmatory factor analysis results

\begin{tabular}{|c|c|c|c|c|c|c|}
\hline Construct & Item & $\begin{array}{l}\text { Contribution } \\
\text { factorielle } \\
\text { St. Loading } \\
\text { factor } \\
\text { (st. error) }\end{array}$ & $\begin{array}{l}\text { Squared } \\
\text { multiple } \\
\text { correlation } \\
\text { SMC }\end{array}$ & $\begin{array}{l}\text { Composite } \\
\text { reliability } \\
\text { (rhô de } \\
\text { Jöreskog) } \\
\rho(\text { A }>0.7\end{array}$ & $\begin{array}{l}\text { Convergent } \\
\text { validity } \\
\rho_{v c}>0.5\end{array}$ & $\begin{array}{l}\text { Discriminant } \\
\text { validity } \\
\rho_{v c}>r^{2}\end{array}$ \\
\hline \multicolumn{7}{|c|}{ Emotionals responses: $\mathrm{X}^{2} / \mathrm{df}=1.124 ; \mathrm{CFI}=1.000 ; \mathrm{NFI}=0.996 ; \mathrm{GFI}=0.992 ; \mathrm{RMR}=0.037 ; \mathrm{RMSEA}=0.018$} \\
\hline \multirow{3}{*}{$\begin{array}{l}\text { Pleasure } \\
\text { Cronbach'œ } \\
=0.933\end{array}$} & Sad / Joyful & 0.918 & 0.842 & & & \\
\hline & Unhappy/Happy & 0.883 & 0.780 & 0.923 & 0.800 & yes \\
\hline & Pessimistic / Optimistic & 0.920 & 0.847 & & & \\
\hline \multirow{3}{*}{ 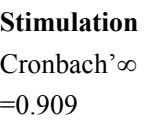 } & Restless/Relaxed & 0.848 & 0.718 & & & yes \\
\hline & Upset/Calm & 0.857 & 0.734 & 0.909 & 0.770 & \\
\hline & Impatient/ Clear mind & 0.927 & 0.860 & & & \\
\hline \multicolumn{7}{|c|}{ Assessment of the overall store environment: $\mathrm{X}^{2} / \mathrm{df}=4.018 ; \mathrm{CFI}=0.988 ; \mathrm{NFI}=0.984 ; \mathrm{GFI}=0.968 ; \mathrm{RMR}=0.048 ; \mathrm{RMSEA}=0.087$} \\
\hline \multirow{6}{*}{$\begin{array}{l}\text { Assessment } \\
\text { of the } \\
\text { overall } \\
\text { store } \\
\text { environme } \\
\text { nt }\end{array}$} & Sad / Joyful & 0.864 & 0.747 & 0.951 & 0.765 & \\
\hline & Unhappy/Happy & 0.843 & 0.711 & & & \\
\hline & Pessimistic / Optimistic & 0.850 & 0.723 & & & \\
\hline & Restless/Relaxed & 0.899 & 0.808 & & & \\
\hline & Upset/Calm & 0.893 & 0.798 & & & \\
\hline & Impatient/ Clear mind & 0.900 & 0.810 & & & \\
\hline \multicolumn{7}{|c|}{ Assessment of the offered products: $\mathrm{X}^{2} / \mathrm{df}=2.688 ; \mathrm{CFI}=0.996 ; \mathrm{NFI}=0.994 ; \mathrm{GFI}=0.997 ; \mathrm{RMR}=0.030 ; \mathrm{RMSEA}=0.065$} \\
\hline \multirow{4}{*}{$\begin{array}{l}\text { Assessment } \\
\text { of the } \\
\text { offered } \\
\text { products }\end{array}$} & Style (modern / outdated) & 0.794 & 0.631 & 0.818 & 0.535 & \\
\hline & choice (suitable / unsuitable) & 0.722 & 0.522 & & & \\
\hline & quality (good / bad) & 0.821 & 0.675 & & & \\
\hline & price (low / high). & 0.561 & 0.468 & & & \\
\hline \multicolumn{7}{|c|}{ Consumer type: $\mathrm{X}^{2} / \mathrm{df}=2.876 ; \mathrm{CFI}=0.978 ; \mathrm{NFI}=0.987 ; \mathrm{GFI}=0.978 ; \mathrm{RMR}=0.072 ; \mathrm{RMSEA}=0.069$} \\
\hline \multirow[t]{4}{*}{ Hedonic } & $\begin{array}{l}\text { This shopping experience was really felt like an } \\
\text { escape. }\end{array}$ & 0.952 & 0.907 & 0.934 & 0.782 & yes \\
\hline & $\begin{array}{l}\text { In comparison to other activities that I have } \\
\text { done, the time spent shopping was really nice. }\end{array}$ & 0.953 & 0.908 & & & \\
\hline & $\begin{array}{l}\text { When shopping, I felt the sensation of } \\
\text { adventure. }\end{array}$ & 0.867 & 0.751 & & & \\
\hline & I loved being surrounded by new products. & 0.750 & 0.562 & & & \\
\hline \multirow[t]{2}{*}{ Utilitarian } & I could not buy what I really needed. & 0.775 & 0.601 & 0.883 & 0.793 & yes \\
\hline & $\begin{array}{l}\text { I made the purchases I wanted during my } \\
\text { shopping experience. }\end{array}$ & 0.993 & 0.986 & & & \\
\hline
\end{tabular}

\section{Copyrights}

Copyright for this article is retained by the author(s), with first publication rights granted to the journal.

This is an open-access article distributed under the terms and conditions of the Creative Commons Attribution license (http://creativecommons.org/licenses/by/3.0/). 